\title{
Tess's Laments
}

\author{
Katarzyna Mosionek
}

Department of English, Maria Curie-Skłodowska University, Poland

Copyright (C) 2016 by authors, all rights reserved. Authors agree that this article remains permanently open access under the terms of the Creative Commons Attribution License 4.0 International License

\begin{abstract}
Thomas Hardy is considered one of the most important and inspiring writers of the turn of the century. The key to his writing is authenticity. Hardy was seized by an impulse, a sudden or recollected emotion which he always tried to preserve in writing. Various emotions ranging from sadness to joy, melancholy to compassion are the canvas for his creative power. Hardy once said that "a poet should express the emotion of all the ages and the thought of his own". So in his own thought he tells the story of grief in Tess's Lament - the poem and Tess of the d'Urbervilles - the novel. Therefore, in my paper I will analyse the sense of loss and the accompanying feeling of grief in these two works of Thomas Hardy.
\end{abstract}

\section{Keywords Thomas Hardy, Lament, Loss, Grief}

\section{Introduction}

The outburst of criticism over the publication of Tess of the d'Urbervilles in 1891 and Jude the Obscure four years later fostered Hardy's decision of devoting fully to poetry which accompanied him from the early beginnings of his literary career. In the centre of Hardy's writing there had always been a man, his feelings and emotionality. Hence, in his works the celebrated writer speaks of sympathy, of experiencing happiness and sadness, joy and grief. He claims that "a poet should express the emotion of all the ages and the thought of his own" [1: p.386]. An example of this is a depiction of Tess's grief in Hardy's poem Tess's Lament ${ }^{1}$ and his famous novel Tess of the d'Urbervilles. Therefore, in my analysis, I am first going to discuss the sense of loss and the feeling of grief and take an attempt to explain how they are exposed in both literary works.

1 Tess is given a lot of attention in Hardy's poetry. The writer refers more or less directly to the novel also in the following poems: We Field-Women, Beyond the Last Lamp, A Maiden's Pledge, The Ruined Maid or The Well-Beloved. The poems appear in different volumes of Hardy's poems but it is really difficult to establish whether they were really written before or after the novel. It is due to the fact that Hardy often changed and revised many of his works created over the years. Poems of Tess are not the only novel-inspired of his works. There are poems exploring some aspects of Under the Greenwood Tree like Friends Beyond, or referring to The Woodlanders- The Pine Planters which seem to prove Hardy's artistry and versatility of his creative power.
Grief is a natural reaction to loss, an intense sorrow and this kind of emotional suffering which is, in most cases, associated with death of someone dear. However, grief is also a reaction to a variety of losses experienced throughout one's life such as impoverishment, health problems or the end of a relationship. Finally, grief is a process, where a grieving person expresses an emotional unsteadiness, hopelessness and helplessness, falls into depression which may also include coping with feelings of anger, guilt or sadness, and is oftentimes tormented by suicidal thoughts. In the light of this Tess's bereavement seems to be overwhelming. Tess, entangled in a series of coincidental events, struggles to cope with the adversities in her life among which are the killing of the family horse Prince, the loss of virginity in the Chase Forest, death of her child Sorrow and, finally, the loss of her beloved Angel Clare.

Tess d'Urberville is one of the most compelling figures in the XIX century literature and one of Hardy's favourite characters. She represents an ideal of femininity combining beauty, strength and passion and, at the same time, is a victim of circumstance beyond her control. For Hardy, she was an embodiment of the rural England he loved and observed disappearing due to the Industrial Revolution. Hardy's belief in external circumstances controlling human actions, the idea of "Fate" - blind to human suffering and joy, makes Tess a far more pitiful creature. In one of the early chapters of the novel Hardy calls Tess "a vessel of emotion untinctured by experience"[2: p.13] at the same time putting an accent to one of the dominants of her personality. Pain that accompanies Tess in her struggle against the circumstances is articulated in the form of laments [3].

\section{The Poem}

Tess's Lament [4] - one of the most popular renderings of the eponymous protagonist - seems to be particularly evocative of certain situations from the novel. It contains allusions to the seduction in the Chase Forest, but most importantly, the poem centres on Tess's breakdown after her separation with Angel Clare. Facing the current emptiness of life without him, Tess reminisces the green and fertile Valley of Dairies which symbolises the plenitude of life with Angel. Yet, the past cannot be restored and the present imposes on 
Tess a heavy burden of pain and suffering. As a result, she sees death as the only way out repeatedly articulating her wish to be forgotten "quite."

Overwhelmed with despondency Tess wishes to "shrink from sight" hoping to efface shame and humiliation. Reminiscing the bygone days of happiness, where she and Clare used to work together in the place remindful of Talbothays farm, Tess glorifies the greatness of Angel's affection emphasising his caring love and tenderness. The third stanza, however, opens with a devastating repetition: "And now he's gone/ and how he's gone/ And now he's gone!" which exposes Tess's longing for Angel and the emptiness of life without him. The scene is further enhanced by the picture of the place. The image from the past "so cosy once and warm" is evocative of Tess's physical wellbeing and comfort, whereas the present setting overrun by weed, "mould and mire" is a metaphoric parallel to the decay of Tess's emotional life. What is more, the juxtaposition of the past and the present also highlights the distance of separation between the lovers and thus deepens her pain. Another stanza opens with Tess's self-accusatory statement "And it was I who did it all" where she takes the blame for the break-up of her marriage with Angel. The neglected wife compares her condition to bearing a Cross.

Fragility of happiness as well as the fear that she is expendable and easily replaced adds its tone to her suffering which is expressed in the line: "how she feels who milks my favourite cow, /and takes my place at churn!." Tess understands that her tragedy and her emotions are meaningless. The final verses of the poem echo its beginning. Tess repeats her death wish revealed in her desire to "unbe." As a matter of fact, the word "unbe" invented by Hardy, aptly encapsulates the heroine's grief. Not only does she want to "turn [her] memory to a blot," but also desires to wipe away painful memories. The words "Make every relic of me rot" repeat her wish of death that would relieve her weary mind from the memories of Angel.

What is more, the melodic line as well as the linguistic layer of the poem is yet another elements serving to expose Tess's grief. The ballad form helps recreate the rhythm of the person crying. In each stanza the last two iambs are repeated in the next verse which creates an impression of an echo. They give effect to the rhythmical but prolonged agony where each echo carries the meaning and affects each stanza and, at the same time, emphasises the phases of Tess's grief. She voices her melancholy, evokes her past moments of comfort, mourns the loss, takes the blame, sounds regretful, and eventually articulates a desire to ease her tired mind. Besides, each stanza is reinforced by numerous alliterations e.g.: "shrink from sight", "stanch and strong", "mould and mire", "blow to fall", "relic of me rot" which also help differentiate between the stages of Tess's grief.

Additionally, the choice of the vocabulary serves the enhancement of the lament. In the poem the author highlights the emotional seesaw of Tess's feelings by a juxtaposition of concrete verbs denoting Tess's wishes: "forget me quite", "claim my nook", "shrink from sight" with words of sentient ascriptions whenever Tess brings back the memories, e.g.: "lie down hopefully", "call me sweet", "whisper words to me", "cosy", "warm or how gay we looked" [5: p.64-65].

\section{The Novel}

The analysis of Hardy's poem redirects a reader's attention to the novel and helps notice that it is woven of numerous laments. It is symptomatic, however, that in most cases in the book, the events causing the laments, are concealed. By concealing the actual event: the killing of Prince, the loss of virginity in the Chase Forest, death of Sorrow, and the loss of Tess's beloved Angel Clare, Hardy centres the reader's attention on the consequence of it and emphasises the emotional context of the novel. Tess and Angel's parting is the only description told in detail. According to Joseph Hillis Miller, Angel is a central figure in Tess's life and the main reason for her eventual demise.

Miller claims that Tess's story is based on a sequence of events which were likely to occur before, but are rearranged in a new pattern. He further contends that it deprives the events "of any purely present existence and makes [them] a design referring backward and forward to a long chain of similar events throughout history"[6: p.120]. Hardy's new pattern for Tess is in accordance with his pessimistic view of life and thus it cannot be other than tragic. The pattern for Tess assumes the confluence and the recurrence of certain facts related to the history of Tess's family which happened over the centuries and their concentration in the life of the main heroine. For example The Chase Forest with its obvious association with hunting, is a displacement of the Vale of Blackmoor - another ancient forest mentioned earlier in the novel -where Tess's home village of Marlott is located. The Vale of Blackmoor is further connected with the legend of the White Hart. During King Henry III's reign there lived a beautiful white hart which was hunted and spared by the King but killed by a certain Thomas de la Lynd. Tess's seduction in the Chase echoes the death of her legendary precursor. In the case of Tess, however, there is no one to take vengeance on the violator. She takes it in her own hands and kills Alec. Thereby she repeats another legend recalled by Alec, where a young lady was killed or killed an obtrusive gentleman who wanted to prevent her escape from the coach. Tess's violation in the Chase Forest repeats the violence her ancestors did to peasant girls of their times. The heroine is doomed to suffer in order to atone for their sins. Legends make the lament more universal and therefore it becomes more powerful. The incident in the Chase, so unexpected for the vulnerable and naïve heroine, evokes the state of shock revealed in her emotional numbness and Hardy's description of her as a "puppet." With time, the accumulation of negative emotions like: disorientation, guilt, or shame bring about her emotional outburst when she addresses her mother: "O mother, my mother! (...) Why didn't you tell me there was 
danger in men-folk? Why didn't you warn me? (...) I never had a chance o'learning in that way, and you did not help me!" [2: p.104].

Another overall pattern leading to Tess's lament is the connection joining her with nature. Paradoxically, giving birth to Alec's child is "doing what comes naturally" and joining the "general life of nature" [6: p.130]. In one of the scenes in the novel Hardy depicts Tess working in the fields with other harvesters and pausing to suckle her child. The poignancy of the scene is reinforced by Hardy's words, "[Tess] has somehow lost her own margin, imbibed the essence of her surrounding, and assimilated herself with it" [2: p.111]. Hardy emphasises Tess's kinship with nature through compassion, care and understanding that she shows to the world of Nature revealed especially in her sympathy towards animals [7]. The grief after Prince's death and the pheasant killing episode prove the point. Tess puts to death a group of wounded birds as she feels connected with these "weaker fellows in Nature" and wants to end their suffering. The scene shows the lament of the whole Nature of which Tess is an embodiment, of Nature devastated, hurt and left alone like the wounded pheasants [8: p. 39-40]. Flintcomb-Ash is another example of Tess's grief reflected in lamenting Nature. Unmerciful, cold and rainy weather welcomes her on her arrival to this barren place, the roughness of which is inscribed in its very name. The winter imagery "the morning frosts" and "the afternoon rains" and the infertile soil make Flintcomb-Ash a desolate and dreary place where there is nothing except "fallow and turnips everywhere", not a single "green pasture" at the "starve-acre place." Flintcomb-Ash represents Tess's lowest emotional state. Her heart is empty and dark like the place in which she finds herself abandoned by Angel. Unlike at Talbothays, "nobody comes near" as she stands "enshrouded in her uniform" working "hour after hour." The monotony of the labour mirrors Tess's emotional lethargy and her loneliness.

However, Tess is a creature of circumstance, subjected to the doings of blind fate, born under the "blighted star" and, therefore, doomed to suffer. The premature death of Sorrow is one of the most heart-breaking scenes in the novel, which brings to the forefront Tess's grief. Being forced to baptize the child herself, Tess names the infant Sorrow. The word "sorrow" is defined as distress caused by loss, affliction, sadness or misfortune. With Tess's past and the way that the boy was conceived, not to mention the sickness that befell him, the name for him is a way of expressing her grief. Despair, fear and anger fused in Tess while she was fighting for Sorrow's salvation leave his mother emotionally drained. Tess turns to God begging Him to have mercy upon the child. However, things go from bad to worse and when the boy dies Tess is denied a proper burial for him. She declares never to come to church again and therefore is forced to bury Sorrow herself in the farmost corner of the cemetery, "the shabby corner of God's allotment, where all unbaptised infants, notorious drunkards, suicides (...) are laid [2: p. 122]. This scene is described from the point of view of someone observing Tess from afar. The distance allows Hardy to show the scale of Tess's grief expressed in a variety of small activities done with tenderness and motherly affection. Silent, focused and calm, Tess places a cross on the child's grave and the flowers at the foot of it, which she puts in a jar labelled "Keelwell's Marmalade."

The final pattern, according to Miller, is tied with the ancient myth by Aristophanes which Hardy might have been inspired by. It tells the story of an ancient race of hermaphrodites formed of a man and a woman joined together to create an entity but divided by gods. The novel's earlier title Too Late Beloved or Too Late, Beloved unfolds the author's idea to construct his work around the net of delays which postpone Angel's love for Tess until it is too late for a happy union. When Tess and Angel fall in love she is already marked with the stigma of "impurity" imprinted on her by Alec [6: p.139]. Tess's confession is also delayed, it happens right after the pair gets married. Before Tess submits to Angel's decision of departure and takes no further action to win him back, she reacts very emotionally receiving rejection rather than forgiveness. A reader may observe Tess being subject to an intense emotional agitation. With all her power she fights to prevent Angel's departure. The choice of the language used to describe Tess's pain in this scene shows the scale of her despair. She cries "a flood of self-sympathetic tears," begs for his mercy, shrieks on the hearing of his cold laughter, speaks in "a dry voice of terror and staggers with pain. The intensity of her emotional reaction fades in the face of Angel's coldness. Paradoxically, he becomes a rather demonic figure stone-hearted and indifferent to Tess's desperate pleas. The scene shows how feeble Angel's concept of naturalness and simplicity is and how strongly he is governed by convention when it seemed he was beyond it [9: p.34-36]. The scene of the parting is very dynamic. Hardy writes,

\section{[Angel] "suddenly broke into a horrible laughter - an unnatural and ghastly as a laugh in hell. -Don't, don't! It kills me quite, that! She shrieked. O, have mercy upon me - have mercy! He did not answer; and, sickly white, she jumped up. -Angel, Angel! (...)I have been hoping, longing, praying, to make you happy! (...) I thought, Angel, that you loved me - me, my very self! (...) Terror was upon her white face (...) her cheek was flaccid, and her mouth had almost the aspect of a round little hole. The horrible sense of his view so deadened her that she staggered" [2: p.293].}

Once Angel leaves, Tess struggles with depression and humiliation connected with her reappearance in Marlott and her father's doubts whether she is really married. Her social and economic status declines with the temporary jobs taken at Flintcomb-Ash. They become more physically demanding. Despite poverty and loneliness she never complains $[10$ : p.41-42]. The only exception when Tess gives herself a 
chance to articulate her pain is by writing two letters to Angel. In the first one, she is wrestling with the temptation that Alec presents, connected with his offer to provide for her impoverished family. The first letter is full of sadness and longing expressed in numerous assurances of faithfulness and affection. The letter ends with a dismal request for Angel's return, "Come to me - come to me and save me from what threatens me!" [2: p.430]. Her second letter, however, is not a plea but an argument that she has been wronged, "O why have you treated me so monstrously, Angel!" [2: p.455]. In a fit of fury, she vows to forget him. Unlike her first letter, the second is a passionate outburst of so long suppressed grief, helplessness and humiliation.

The state of the prolonged pain, suppressed feelings, Angel's reappearance and his plea for Tess's forgiveness eventually lead her to kill Alec. Angel's arrival comes too late which Tess signals with the words, "I say it's too late (...) I waited and waited for you" [2: p.484]. Silence that falls between Tess and Angel is the most meaningful way to expose despair and an overwhelming sense of entrapment. The delays in the reunion with Angel - her ideal second half add a mythical value to the lament. Tess becomes a symbol of a woman defeated by fate.

The words of her lament turned against Alec are Tess's cry of helplessness and disillusionment. The reader has a chance not only to hear Tess moaning, but also sees her kneeling in despair. Tess finally lists her grievances against Alec. She resents his cruel persuasion and his mockery that her husband would never return. She finally believed him, but now her husband has returned. This is her final outburst before the climactic scene - the murder. Tess moans, "You have torn my life all to pieces ... made me what I prayed you in pity not to make me again! (...) I can't bear this! - I cannot!" [2: p.487]. Shortly afterwards the red spot of blood on the ceiling signals that the crime has been committed. It is interesting how Tess's wish of death articulated in the poem and repeated numerous times in the novel actually finds its fulfilment shortly after the moment of perfect happiness. Tess's life goes on, "the vessel of emotion" that she is, becomes tinctured by the experience of suffering and pain until the moment she is able to reunite with Angel. The pair spends together a few days in Brumshurts manor completely forgetting about their previous estrangement. Miller notices, however, that "completeness is death" [6: p.138]. Laurence Estanove claims that the laments in the novel are arranged in a melody of a cry which ends with a sigh, the metaphor of which is the scene in Stonehenge. The sigh is the moment when Tess's lament grows silent, it is the metaphor of her last breath. The laments, so filled with grief, bitter, "irremediable", "mad", and "violent" finally come to an end [11: p.39-40].

\section{The Conclusions}

The conclusion that might be drawn from the study of Tess's laments in Hardy's works is that although the poem leaves space for interpretation and deepened analysis of certain facts of Tess's life, the true reasons of her laments are explicated in the novel. The laments become the structural intensification of Tess's tragedy. The motif of her unity with Nature, legends and the typicality of human fate in general add to the universality of the laments. The analysis reveals that Tess does not grieve because of the harm that has been done to her, but because of the harm she, in her perception, has caused to other people - "It was I who did it all."

\section{REFERENCES}

[1] Hardy, Florence Emily. The Early Life of Thomas Hardy, 1840-1891. London: Macmillan, 1928.

[2] Hardy, Thomas. Tess of the d'Urbervilles. London: Penguin Popular Classics, 1994.

[3] Shaw, Will. "Tess's Lament and Characterisation" $<$ https://www.youtube.com/watch? $\mathrm{v}=\mathrm{tmk} 5 \mathrm{MNqffc} 4>$

[4] Hardy, Thomas. Tess's Lament.

$<$ http://www.daypoems.net/poems/1080.html>

[5] Bandyopadhyay, Bidyut. "The Nature and Function of Verbs in Thomas Hardy's Poetry." The Hardy Review, Vol. XIII No.1 (2011): 64-73.

[6] Miller, Hillis J. Fiction and Repetition: Seven English Novels. Cambridge : Harvard University Press, 1982.

[7] "Phase The Fifth: The Woman Pays. The Animal and Hunt Imagery"

http://academic.brooklyn.cuny.edu/english/melani/novel_19c /hardy/flint.html>

[8] Grosso, Stefania. "Tess: Nature and Paganism." Hellenism, Paganism and Aestheticism: Arnold's Influences on Hardy's Later Novels. Venezia: Universita Ca Foscari, 2004. 39-50.

[9] Grosso, Stefania. "Angel as a "Sample Product of the Last Five-and-twenty Years." Hellenism, Paganism and Aestheticism: Arnold's Influences on Hardy's Later Novels. Venezia: Universita Ca Foscari, 2004. 31-39.

[10] Zhen, Chen. "Tess in Thomas Hardy's Tess of the d'Urbervilles - Victim of Social Prejudice and Male Dominance in Victorian Patriarchal Society". http://www.ritsumei.ac.jp/acd/cg/lt/rb/600/600PDF/chen.PD F

[11] Estanove, Laurence. "A Lament and a Sigh: Voicing Disillusionment in Thomas Hardy's Verse." The Hardy Review, Vol. XI No. 1 (2009): 31-40. 